\title{
EFFECT OF HEAT PRE-TREATMENT AND EXTRUSION ON THE STRUCTURE AND MECHANICAL PROPERTIES OF WZ21 MAGNESIUM ALLOY
}

\author{
VPLIV TOPLOTNE OBDELAVE IN IZTISKOVANJA NA \\ STRUKTURO IN MEHANSKE LASTNOSTI MAGNEZIJEVE \\ ZLITINE WZ21
}

\author{
Drahomír Dvorský $^{1}$, Jiří Kubásek ${ }^{1}$, Dalibor Vojtěch ${ }^{1}$, Miroslav Čavojský ${ }^{2}$, Peter Minárik ${ }^{3}$ \\ ${ }^{1}$ Faculty of chemical technology, Department of metals and corrosion engineering, University of chemistry and technology Prague, \\ Technická 5, 16628 Praha 6 - Dejvice, Czech Republic \\ ${ }^{2}$ Institute of Materials and Machine Mechanics SAS, Slovak Academy of Sciences, Dúbravská cesta 9, 84513 Bratislava, Slovak Republic \\ ${ }^{3}$ Charles University, Faculty of Mathematics and Physics, Ke Karlovu 3, 12116 Praha 2, Czech Republic \\ dvorskyd@vscht.cz
}

Prejem rokopisa - received: 2017-12-12; sprejem za objavo - accepted for publication: 2018-02-15

doi:10.17222/mit.2017.214

\begin{abstract}
The magnesium alloy WZ21 was prepared by a combination of conventional casting, extrusion and heat treatment. The effect of various processing conditions on the final structure, mechanical and corrosion properties were investigated. Long-period stacking ordered (LPSO) phases were observed in the as-cast structure; however, they were at least partially dissolved during the extrusion or heat treatment. Thermally stable $\mathrm{Mg}_{24} \mathrm{Y}_{5}$ was observed in the structure as another dominant phase. The application of heat treatment to extruded products causes significant grain growth, and, therefore, the loss of mechanical properties. On the contrary, heat treatment performed before extrusion has a strong positive effect on the observed mechanical properties. In both cases, the thermal treatment positively affected the corrosion resistance of the prepared materials although the effect is more significant for material annealed before extrusion. After appropriate processing, the WZ21 alloy was characterized by the high value of the tensile yield strength of $337 \mathrm{MPa}$ and really promising corrosion rate in simulated body fluid (SBF) $(0.75 \mathrm{~mm} /$ year $)$.

Keywords: magnesium, extrusion, mechanical properties, grain size, corrosion
\end{abstract}

Avtorji članka so magnezijevo zlitino WZ21 pripravljali s kombinacijo konvencionalnega litja, iztiskovanja (ekstruzije) in toplotne obdelave. Raziskovali so vpliv različnih procesnih pogojev na končno mikrostrukturo, mehanske in korozijske lastnosti. Opazili so urejenost dolgega dosega (LPSO; angl.: Long-Period Stacking Order) faz v liti strukturi, ki pa so bile vsaj delno raztopljene (razgrajene) med ekstruzijo ali toplotno obdelavo. $\mathrm{Mg}_{24} \mathrm{Y}_{5}$ je druga dominantna termično stabilna faza v strukturi. Uporaba toplotne obdelave na ekstrudiranih proizvodih povzroči znatno rast kristalnih zrn in zato poslabšanje mehanskih lastnosti. Nasprotno ima toplotna obdelava pred ekstruzijo močan pozitivni učinek na opazovane mehanske lastnosti. V obeh primerih ima toplotna obdelava pozitiven učinek na korozijsko odpornost pripravljenih materialov. Vendar je učinek bolj izrazit pri materialih, žarjenih pred ekstruzijo. Po primernem procesiranju so Mg zlitino WZ21 analizirali in ugotovili, da ima visoko mejo tečenja (337 MPa) in zelo obetavno korozijsko hitrost v simulirani telesni tekočini $(0,75 \mathrm{~mm} / \mathrm{leto})$.

Ključne besede: magnezij, ekstruzija, mehanske lastnosti, velikost zrn, korozija

\section{INTRODUCTION}

Magnesium alloys offer advantages in the form of low density, relatively good mechanical properties and good stiffness. ${ }^{1}$ Those benefits are attractive, especially for the automotive and aviation industries. ${ }^{2}$ However inferior mechanical properties, low ductility and low heat stability limits its spread of use..$^{2,3}$ Therefore, many studies have been done to improve the mechanical properties of magnesium alloys. Magnesium is the eighth most abundant element on Earth and is easily recyclable, which contributes to environmental protection. ${ }^{3}$ The biocompatibility and degradation performance of magnesium and its alloys makes them suitable materials for biodegradable implants. ${ }^{4}$ The idea of biodegradable implants is based on the gradual degradation of the implant, while the bone heals and grows in the area of the degraded implant. ${ }^{1}$ This means that only one operation is necessary. It leads to a decrease in the price of the operation as well as to increased comfort of the patient. ${ }^{5}$ The main advantage of magnesium is in non-toxicity and the low Young's modulus, which is much closer to the cortical bone than other permanent biomaterials like stainless steel or Ti and its alloys. ${ }^{4}$ The stress-shielding effect occurs in materials with a high Young's modulus and complicates the bone ingrowth.

The biodegradable implant should sustain its mechanical properties for at least 8 weeks with ultimate dissolution in 12-15 months; therefore, the optimal corrosion resistance is necessary. ${ }^{5}$ Magnesium and most of its alloys have a rapid corrosion rate, which generates hydrogen. Hydrogen bubbles complicate bone ingrowth; however, if the hydrogen is released slowly and uniformly, then it is easily taken away. Another danger is the great gradient of $\mathrm{pH}$ nearby the corroding implant, 
which is lethal to the bone cells. Slow and uniform corrosion is the key to the usability of the biodegradable implant. The great danger lies in more noble elements insoluble in a magnesium matrix, especially $\mathrm{Fe}, \mathrm{Ni}$ and $\mathrm{Cu}^{6}{ }^{6}$ Those elements have to be held beneath a certain level of $\mathrm{mg} / \mathrm{kg}$, otherwise their presence has fatal consequences on the corrosion performance. Pure magnesium is more prone to impurities then alloys because some alloying elements can absorb them. However, high-purity magnesium exerts better corrosion resistance than most magnesium alloys, especially thanks to the absence of secondary phases. ${ }^{7}$

Different magnesium-based alloys usually derived from magnesium alloys used in industry were investigated as possible biodegradable materials. However, the toxicity of alloying elements has to be taken into consideration. For example, the presence of aluminum in alloys from the AZ series contributes to Alzheimer's disease. ${ }^{8}$ Rare-earth elements seem to be a good choice for alloying of magnesium as they improve the mechanical and corrosion properties. The cytocompatibility of rare-earth elements was studied on human cells with positive results. Moreover, they are used as an anti-carcinogenic reagent in small doses. However, the long-term toxicity has to be investigated as rare-earth elements concentrate in large bones. Still, the usability of WE alloys (such as WE43) is in fact really close to the final commercial application in medicine.

Research is nowadays focused on the reduction or substitution of RE alloying elements with more compatible ones. In this case, $\mathrm{Zn}$ is often considered as a suitable alloying element because it is essential for the human organism and in many cases improves the mechanical properties of magnesium-based alloys by solid solution strengthening. ${ }^{9}$ The easy absorption of zinc in-vivo was observed for alloys with the zinc mass content of about $1 \%$.

Based on these characteristics the WZ21 alloy, containing $\mathrm{Y}$ and $\mathrm{Zn}$ as the main alloying elements, is considered as a possible biodegradable material. This alloy was reported to have promising results of low and uniform corrosion rate, and good cytocompatibility. ${ }^{4}$ The $\mathrm{Mg}-\mathrm{Y}-\mathrm{Zn}$ system has also been recently studied for its excellent mechanical properties and unique microstructures. $^{3}$ In the Mg-Y-Zn system, several secondary phases (quasicrystalline I-phase $\left(\mathrm{Mg}_{3} \mathrm{Zn}_{6} \mathrm{Y}\right), \quad \mathrm{W}$-phase $\left(\mathrm{Mg}_{3} \mathrm{Zn}_{3} \mathrm{Y}_{2}\right)$, and long period stacking ordered (LPSO) phases) are formed depending on the $\mathrm{Y} / \mathrm{Zn}$ ratio. ${ }^{4}$ The $\mathrm{Mg}_{24} \mathrm{Y}_{5}$ cubic phase is also present in Mg-Y-Zn alloys. ${ }^{10}$ The icosahedral I-phase $\left(\mathrm{Mg}_{3} \mathrm{Zn}_{6} \mathrm{Y}\right)$ is observed in alloys with high $\mathrm{Zn}$ content. It is relatively thermally stable, it causes an increase of hardness and corrosion resistance. ${ }^{4}$ Its presence in the structure effectively suppresses the grain growth. ${ }^{11}$ The higher amount of this phase is known to improve the strength of Mg-Y-Zn alloys. ${ }^{12}$ On the contrary, the cubic incoherent W-phase ineffectively pins the grain boundaries during thermomechanical processing and negatively affects the mechanical properties. ${ }^{4,13}$ It can be at least partially removed from the material by proper annealing. ${ }^{14}$ LPSO phase occurs in the alloys with lower $\mathrm{Zn}$ content. Different kinds of LPSO phase exist $(6 \mathrm{H}, 10 \mathrm{H}, 14 \mathrm{H}, 18 \mathrm{R}, 24 \mathrm{R}, \mathrm{H}=$ hexagonal, $\mathrm{R}=$ rhombohedral). ${ }^{15}$ The presence of this phase positively affects strength and plasticity of the alloy. ${ }^{2}$ Kawamura et al. ${ }^{16}$ prepared WZ21 alloy containing LPSO phases with the incredible yield strength of $610 \mathrm{MPa}$ and elongation of $5 \%$ at room temperature.

Extrusion is a common processing method for magnesium alloys. Extruded magnesium alloys are generally characterized by a specific texture, which causes the anisotropy of the mechanical properties and deteriorates the plasticity of the material. However, recent studies have shown that ductility, tensile yield strength (TYS) and ultimate tensile strength (UTS) can be spontaneously improved by the formation of a microstructure with a low grain size and the suppression of grain growth during processing by small secondary phases, which pin the grain boundaries. In such a case, pyramidal c+a slip systems are activated more easily in fine-grained materials, which partially prevents the formation of specific textures by recrystallization processes during extrusion, and therefore, improve the ductility. ${ }^{1}$ The texture of a magnesium alloy is strongly affected, especially by rare-earth (RE) elements, which are known to form a so-called "RE texture". ${ }^{1}$

This paper is focused on the preparation of $\mathrm{Mg}-2 \mathrm{Y}-$ $1 \mathrm{Zn}$ alloy by extrusion. This alloy may offer a good combination of mechanical properties and corrosion resistance depending on the structure of the material. It is also considered as a promising candidate for application in medicine. The presented alloy was prepared by the conventionally available extrusion process and the effect of heat treatment applied before and after extrusion process on the structure, mechanical and corrosion properties are studied. The presented results confirm the good mechanical properties of this alloy, which are associated with the full recrystallization and the related small grain size. The corrosion tests reveal the positive effect of the heat treatment on the corrosion resistance. Although a solution treatment of this alloy causes a significant decrease in the corrosion rate, our results confirmed that it should be performed predominantly before extrusion, not after in order to sustain small grains and good mechanical properties.

\section{EXPERIMENTAL PART}

\subsection{Materials}

The WZ21 magnesium alloy was prepared by melting pure elements of $\mathrm{Mg}, \mathrm{Y}$ and $\mathrm{Zn}$ in the induction furnace at $750{ }^{\circ} \mathrm{C}$ for $15 \mathrm{~min}$ under the protective argon atmosphere. The as-cast ingot was then heat treated at $525^{\circ} \mathrm{C}$ for $8 \mathrm{~h}$ followed by quenching in water. Cast and heat treated ingots were then extruded at $350{ }^{\circ} \mathrm{C}$ with 
Table 1: Composition of simulated body fluid

\begin{tabular}{|c|c|c|c|c|c|c|c|c|}
\hline$(\mathrm{mmol} / \mathrm{L})$ & $\mathrm{Na}^{+}$ & $\mathrm{K}^{+}$ & $\mathrm{Mg}^{2+}$ & $\mathrm{Ca}^{2+}$ & $\mathrm{Cl}^{-}$ & $\mathrm{HCO}_{3}^{-}$ & $\mathrm{HPO}_{4}{ }^{2-}$ & $\mathrm{SO}_{4}{ }^{2-}$ \\
\hline SBF & 142.0 & 5.0 & 1.5 & 2.5 & 148.5 & 4.2 & 1.0 & 0.5 \\
\hline
\end{tabular}

extrusion ratio 16 and extrusion speed $0.3 \mathrm{~mm} / \mathrm{s}$. Final extruded products were rods with a $7.5 \mathrm{~mm}$ diameter.

\subsection{Microstructure}

Samples were ground on $\mathrm{SiC}$ grinding papers (P80-P4000) and subsequently polished on diamond paste. The final polishing for structure observation by scanning electron microscopy (SEM) was performed on Topol 2 with fine particles of $\mathrm{Al}_{2} \mathrm{O}_{3}$. The final mechanical polishing for EBSD analysis was done on Etosil $\mathrm{E}$ and neoprene cloth without subsequent etching. Samples for microstructure analysis were etched in a solution containing $10 \mathrm{~mL}$ of acetic acid, $4.2 \mathrm{~g}$ picric acid, $10 \mathrm{~mL}$ distilled water and $70 \mathrm{~mL}$ ethanol. The microstructure was studied by scanning electron microscopy SEM (TescanVEGA3 equipped with energy dispersion spectrometry - EDS, Oxford instruments and NordlysMax electron back-scattered diffraction (EBSD) detector, and AZtecHKL software). Subsequent parameters were selected for EBSD analysis: working distance $=15 \mathrm{~mm}$, accelerating voltage $=20 \mathrm{kV}$, dwell-exposure time $=$ $0.26 \mathrm{~s} / \mathrm{pt}$, step size $=0.25 \mu \mathrm{m}$, binning mode $4 \times 4$, frame averaging $=3$ times).

\subsection{Mechanical properties}

Compression tests were performed on LabTest 5.250SP1-VM at room temperature on cylindrical samples with $6 \mathrm{~mm}$ in diameter and $9 \mathrm{~mm}$ high. A constant deformation speed of $0.001 \mathrm{~s}^{-1}$ was selected. Compressive yield strength (CYS), ultimate compressive strength (UCS) and total deformation were determined. Tensile properties were measured on the same machine at room temperature on samples with $3.5 \mathrm{~mm}$ in diameter in the constricted area and $25 \mathrm{~mm}$ in length. A constant deformation speed of $0.001 \mathrm{~s}^{-1}$ was selected. The tensile yield strength (TYS), ultimate tensile strength (UTS) and elongation were determined.

\subsection{Corrosion behavior}

Corrosion tests were carried out in simulated body fluid (SBF) (Table 1). The temperature was set to $37^{\circ} \mathrm{C}$ and time of exposure was two weeks. Samples were ground on the $\mathrm{SiC}$ grinding paper (P2500), rinsed with distilled water and ethanol before the immersion tests. Exposure was performed in closed plastic containers in $100 \mathrm{~mL}$ of SBF per $1 \mathrm{~cm}^{2}$ of surface area. The specific concentrations of the ions in SBF are shown in Table 1. The SBF was prepared by mixing solutions of $\mathrm{KCl}$, $\mathrm{NaCl}, \mathrm{NaHCO}_{3}, \mathrm{MgSO}_{4} \cdot 7 \mathrm{H}_{2} \mathrm{O}, \mathrm{CaCl}_{2}$, TRIS, (tris(hydroxymethyl)aminomethane), $\mathrm{KH}_{2} \mathrm{PO}_{4}$ in that order. An experiment was carried out without changing of the SBF.
The $\mathrm{pH}$ of the fluid rose from $\mathrm{pH} 7.6$ to 8.2. After the immersion tests, the samples were rinsed in distilled water and the corrosion products were removed by the solution of $200 \mathrm{~g} \cdot \mathrm{L}^{-1} \mathrm{CrO}_{3}, 10 \mathrm{~g} \cdot \mathrm{L}^{-1} \mathrm{AgNO}_{3}, 20 \mathrm{~g} \cdot \mathrm{L}^{-1}$ $\mathrm{Ba}\left(\mathrm{NO}_{3}\right)_{2}$. The corrosion rate was calculated from weight changes and from magnesium ions released to the solution during the immersion tests.

\section{RESULTS AND DISCUSSION}

\subsection{Microstructure}

The structure of the as-cast Mg-2Y-1Zn (AC) is displayed in Figure 1a. It is characterized by a dendritic structure, where the alloying elements are segregated especially at the dendrite edges. The dendrites consist of the $\alpha$-Mg matrix and intermetallic phases. Intermetallic phases were elongated and narrow or round shaped. According to the EDS analysis, the atomic ratio between $\mathrm{Y}$ and $\mathrm{Zn}$ in the intermetallic phases was $1: 1{ }^{3}$ Such a ratio indicates the presence of the LPSO phase $\left(\mathrm{Mg}_{12} \mathrm{ZnY}\right)$, which has already been observed in alloys with $\mathrm{Y} / \mathrm{Zn}$ weight ratio equal to $2: 1$, which is in good accordance with the presented results. ${ }^{17}$ On the contrary, Cabeza et al. ${ }^{4}$ investigated the presence of two morphologies - binary eutectic pockets (Y/Zn ratio of 1:2) and LPSO phase (Y/Zn ratio of $1: 1$ ). The $\alpha-\mathrm{Mg}$ solid solution contained about $0.3 \%$ of mass fractions of $\mathrm{Y}$ and $0.3 \%$ of mass fractions of $\mathrm{Zn}$. Therefore, the majority of the alloying elements are contained in intermetallic phases.

Extrusion of the as-casted ingot (Ex) results in strong specific orientation of the microstructure constituents, (Figure 1b) such as intermetallic phases ordered in rows parallel to the extrusion direction. A small fraction of intermetallic phases dissolved in the matrix during extrusion and dendritic microsegregation was almost removed. As a consequence, the solid solution of $\alpha-\mathrm{Mg}$ consists of $1.3 \%$ of mass fractions of $\mathrm{Y}$ and $0.8 \%$ of mass fractions of $\mathrm{Zn}$. Still, there exists areas of residues of dendritic microsegregation coming from the as-cast state, which contains about $5.6 \%$ of mass fractions of $\mathrm{Y}$ and $3.4 \%$ of mass fractions of $\mathrm{Zn}$. Similar behavior including the partial dissolution of LPSO phase during was observed by Zhang et al. ${ }^{13}$ The grain size of extruded ingot ranged from $0.5 \mu \mathrm{m}$ to $7 \mu \mathrm{m}$. The presented intermetallic phases pin the grain boundaries and work as obstacles for grain growth during dynamic recrystallization accompanying the extrusion process at high temperature. ${ }^{12}$

After proper annealing $\left(525{ }^{\circ} \mathrm{C}\right.$ for $8 \mathrm{~h}$ followed by quenching) of the as-extruded sample (ExT4), the residues of dendritic microsegregation and some interme- 


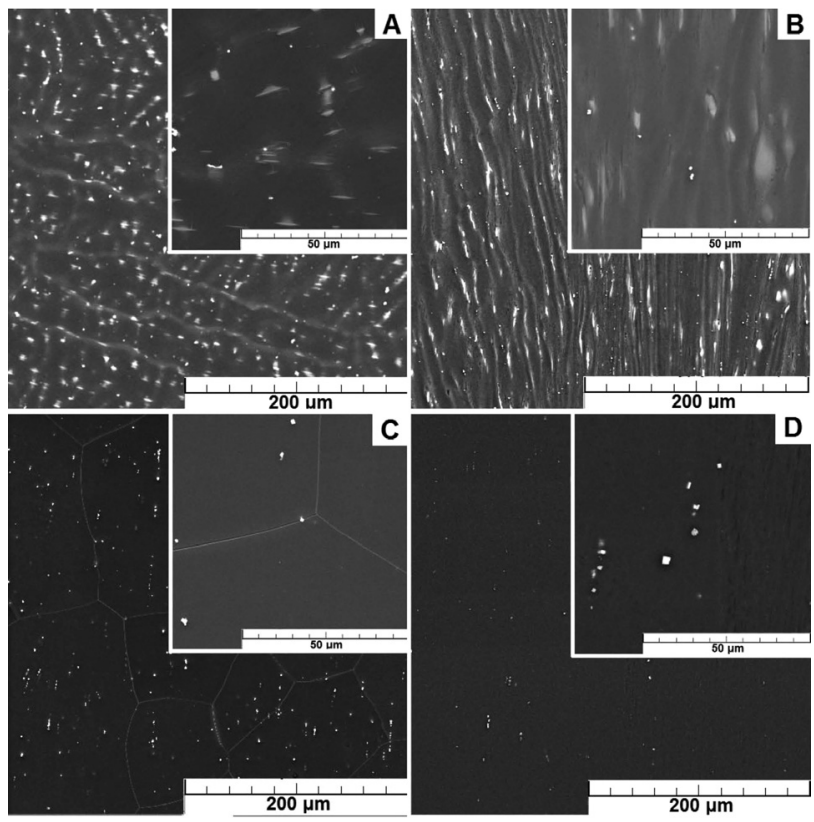

Figure 1: Microstructure of Mg-2Y-1Zn alloy after different processing (SEM): a) As-cast state (AC), b) Extruded state (Ex), c) Extruded state subsequently heat treated (ExT4), d) Heat-treated state subsequently extruded (T4Ex)

tallic phases were dissolved in the matrix (Figure 1c). Only the heat stable binary $\mathrm{Mg}_{24} \mathrm{Y}_{5}$ phase remained in the structure. Zinc is completely dissolved in the matrix. This annealing also causes strong coarsening of the structure of the alloy, as can be seen in Figure 1c. The grain size of material ranged between $50 \mu \mathrm{m}$ and $300 \mu \mathrm{m}$. The solid solution contained about $1.2 \%$ of mass fractions of $\mathrm{Y}$ and $1.0 \%$ of mass fractions of $\mathrm{Zn}$. The solid solution was homogenized during processing. Subsequently, the global concentration of $\mathrm{Zn}$ and $\mathrm{Y}$ in the solid solution is similar to the extruded material.

The extrusion process was performed alternatively on the as-cast sample thermally heat pre-treated $\left(525^{\circ} \mathrm{C}\right.$ for $8 \mathrm{~h}$ followed by quenching) (T4Ex) (Figure 1d). In this case, the majority of the eutectic phases were dissolved and only the thermally stable $\mathrm{Mg}_{24} \mathrm{Y}_{5}$ phase stays in the structure during annealing. The solid solution of extruded specimen consists of $1.8 \%$ of mass fractions of $\mathrm{Y}$ and $1.1 \%$ of mass fractions of $\mathrm{Zn}$. It is worth mentioning that the concentration of alloying elements in solid solution was the highest in this case. If the thermal treatment is applied on the as-cast state, the majority of the eutectic phases can be dissolved and the concentration of alloying elements in the solid solution is increased. On the contrary, during extrusion of the as-cast material, precipitation can partially take place in areas with an increased concentration of $\mathrm{Y}$ and $\mathrm{Zn}$. These precipitates are stable or even coarsen during subsequent annealing, and therefore the concentration of $\mathrm{Y}$ in solid solution remains low (1.2\% of mass fractions). The alloy extruded after thermal pre-treatment was characterized by small equiaxed grains with the grain size similar

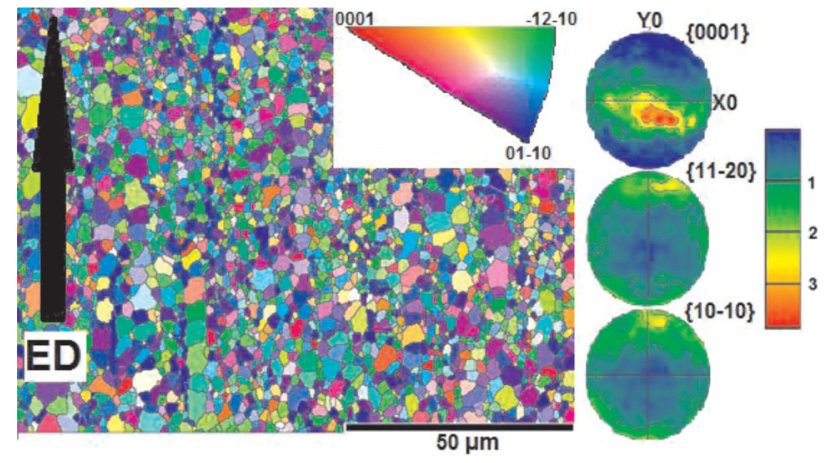

Figure 2: EBSD orientation map of Mg-2Y-1Zn alloy prepared by extrusion of as-cast state: EBSD map and pole figures of the extruded ingot (Y0 reflects the extrusion direction (ED))

as in the case of directly extruded as-cast state (0.5-7 $\mu \mathrm{m})$. Such an observed structure is the result of dynamic recrystallization during extrusion.

Both extruded alloys were analyzed using electronbackscatter diffraction (EBSD) (Figure 2). Due to the similarities in results obtained for both states, only the EBSD map and pole figures for $\mathrm{Mg}-2 \mathrm{Y}-1 \mathrm{Zn}$ are shown. It is evident from Figure 2 that the majority of grains are oriented with the basal planes parallel to the extrusion direction. The maximum texture intensity of 3.8 was measured. Such texture can subsequently affect the mechanical properties. The results of the EBSD analysis for the extruded sample were similar as for the sample prepared by the extrusion of a heat-treated ingot. Based on the obtained results (Figure 2), the material is recrystallized completely and no strongly deformed elongated areas were observed.

\subsection{Mechanical properties}

Compressive and tensile properties of the prepared samples were measured and the results are summarized in two diagrams in Figures 3 and 4. Similar properties were observed for the as-cast ingot (AC) and for the extruded sample processed by subsequent annealing (ExT4). The similarity was also observed for samples extruded directly from the as-cast state (Ex) and from the heat-treated ingot (T4Ex). Weaker mechanical properties such as CYS, TYS, UCS, and UTS of AC and ExT4 are mainly contributed to the large grains. Large grains also increase the plasticity of the material in this case. Large grain size and specific grain orientation after extrusion support the twinning mechanism. ${ }^{18}$ Such behavior can be recognized in Figure 5 in some plateau after yielding. Beyond the yield strength there exists in all cases an area of lower strengthening (plateau), where the twinning mechanism occurs. In the last part of the compressive curve (Ex, T4Ex), the slope of stress-strain dependence is again increased as a result of higher activation energies for advanced slip systems. Slightly higher concentration of alloying elements in the solid solution and 


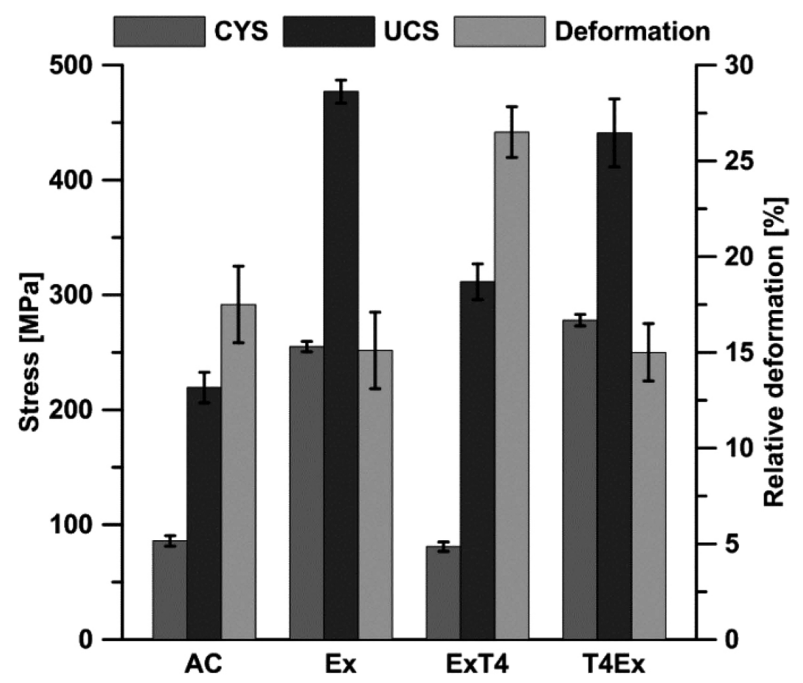

Figure 3: Compressive properties of Mg-2Y-1Zn alloy (CYS, UCS)

homogeneous structure in ExT4 sample cause increase in the ultimate compressive strength. ${ }^{19}$

Just a slight improvement of the mechanical properties can be observed for T4Ex compared with the just extruded sample. This minor improvement is also contributed to the solid-solution strengthening as well as by the more homogeneous structure. However, both materials had strongly reduced plasticity as a consequence of the texture of the material. ${ }^{20}$ This fact is supported by the anisotropy of the mechanical properties in tension and compression, which was observed for the extruded samples (Figure 2). The measured compressive yield strengths were lower than the tensile yield strengths, which is associated with the easy activation of the twinning mechanism during the compression testing. ${ }^{21}$ The winning is directionally dependent. The typical magnesium basal texture means that most of the grains orient their basal planes (0001) parallel with the extrusion direction. If such a structure is pressed in parallel to the extrusion direction then the twinning mechanism

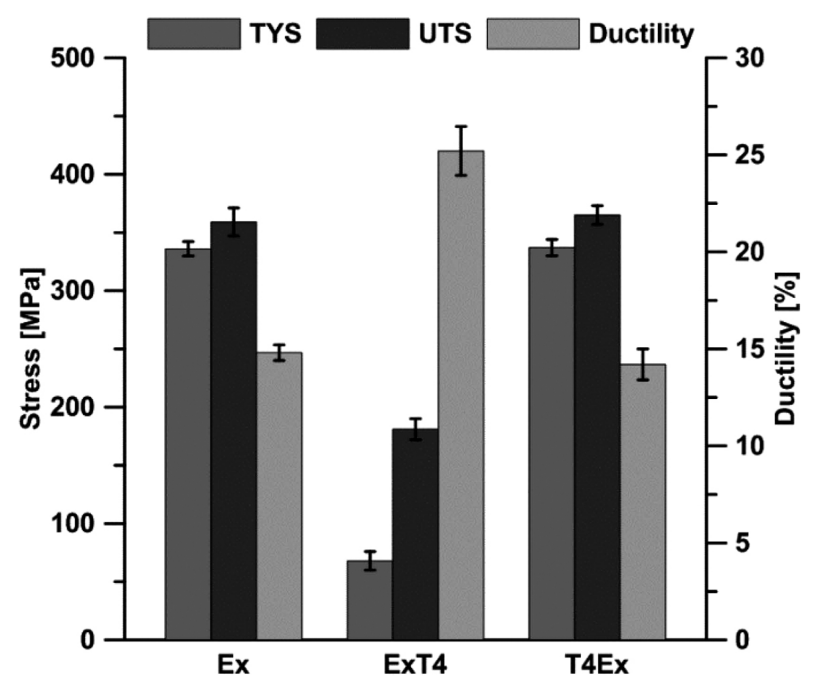

Figure 4: Tensile properties of Mg-2Y-1Zn alloy (TYS, UTS)

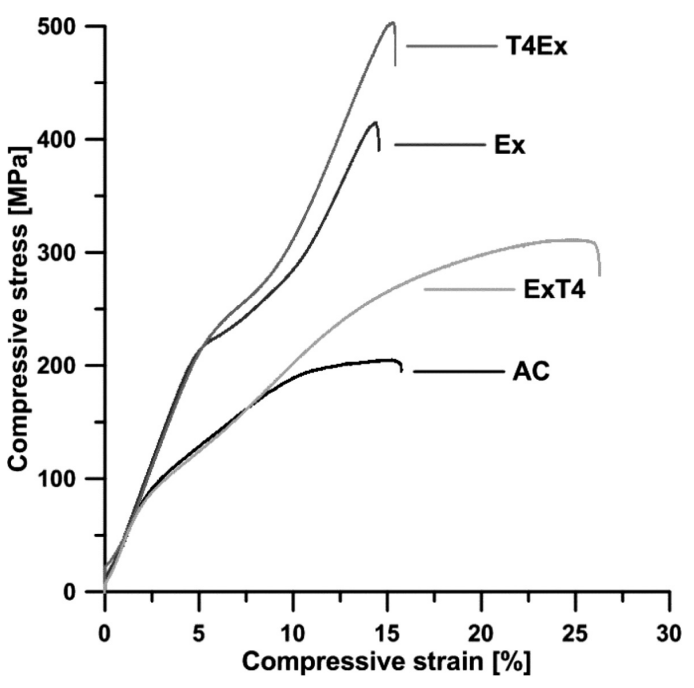

Figure 5: Compressive curves of $\mathrm{Mg}-2 \mathrm{Y}-1 \mathrm{Zn}$ processed in different ways

occurs easily. On the contrary, if the tensile force is applied in parallel to the extrusion direction, the twinning mechanism is suppressed and the basal slip is difficult due to preferential texture and grain orientation. ${ }^{22}$ The highest value of the tensile yield strength reached up to $337 \mathrm{MPa}$, which is higher than was achieved by Cabeza et al. ${ }^{4}(211 \mathrm{MPa})$. They prepared samples by extrusion at the same temperature but with extrusion ratio of 32 . Huan et al. ${ }^{2}$ reached lower ultimate tensile strength $(320 \mathrm{MPa})$ and elongation of $11.2 \%$ however they used higher temperature of $450{ }^{\circ} \mathrm{C}$ and extrusion ratio 9 .

\subsection{Corrosion}

Corrosion behavior was studied on immersion tests in simulated body fluid (SBF) at $37^{\circ} \mathrm{C}$ for two weeks. Each sample was immersed in the closed container in approximately $300 \mathrm{ml}$ of SBF. The final corrosion rates were calculated from weight changes and concentration of released magnesium ions in the corrosion environment. The highest corrosion resistance was obtained for materials that were exposed to proper annealing (Figure 6). Increased corrosion resistance is caused by different effects. Firstly, heat-treated materials are characterized by more homogeneous structures with lower content of intermetallic phases and also absence of dendritic microsegregation. Both these effects have a negative impact on the corrosion rate of the studied material because they accelerate the dissolution of magnesium alloy and support the existence of localized corrosion. ${ }^{23}$ A slightly lower corrosion rate of alloy processed by heat pre-treatment and subsequent extrusion is associated with the higher amount of alloying elements (especially Y) in solid solution, which is known to improve the corrosion resistance by incorporating $\mathrm{Y}$ in protective oxide layers which are formed during corrosion. ${ }^{24}$ The corrosion rate of the sample extruded from the as-cast state is characte- 


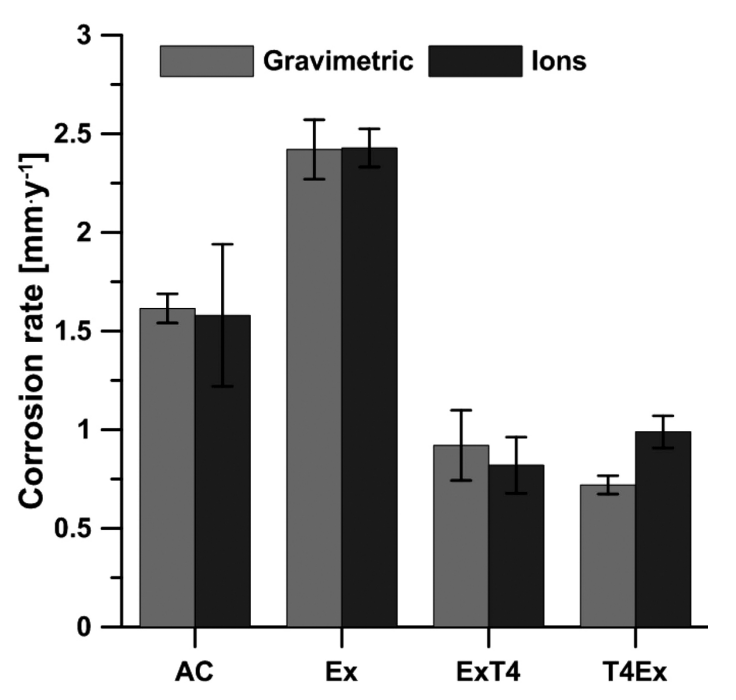

Figure 6: Corrosion properties of $\mathrm{Mg}-2 \mathrm{Y}-1 \mathrm{Zn}$ processed by different ways

rized by highest corrosion rate, almost one-third higher compared to the as-cast state. In both states, microsegregation is observed in the microstructure. However, in the case of as-cast specimen, dendrites and its boundaries enriched by $\mathrm{Y}$ and $\mathrm{Zn}$ are distributed more homogeneously. Such areas may partially work as a barrier for spreading of the corrosion, like in the case of $\mathrm{Mg}_{17} \mathrm{Al}_{12}$ phase in AZ31 alloys. ${ }^{25}$ This is quite different in the case of extruded specimen, because here alternate rows enriched and depleted by $\mathrm{Y}$ and $\mathrm{Zn}$. As a consequence, corrosion may be spread more easily in continuous rows depleted by $\mathrm{Y}$ and $\mathrm{Zn}$. The obtained corrosion rates are much lower compared to the work of Cabeza et al. $^{4}$ (6.8 mm/year). They calculated the corrosion rate out of released hydrogen for the first $144 \mathrm{~h}$ with the tendency to slow down the corrosion, so the final corrosion rate might be lower after two weeks. Nevertheless, a high corrosion rate was caused by the numerous intermetallic phases which worked as cathodic areas and accelerate corrosion by micro-galvanic cells. This is in accordance with our observations. The absence of intermetallic phases in heat-treated samples resulted in the significant improvement of corrosion resistance.

\section{CONCLUSIONS}

The Mg-2Y-1Zn magnesium alloy was prepared by conventional methods including casting, thermal treatment $\left(525{ }^{\circ} \mathrm{C} / 8 \mathrm{~h}\right)$, and extrusion at $350{ }^{\circ} \mathrm{C}$. The as-casted ingot was characterized by the presence of a dendritic structure and LPSO phases. The extrusion process provides a fine-grained structure with an average grain size ranging from $0.5 \mu \mathrm{m}$ to $7 \mu \mathrm{m}$. The LPSO phases partly disappeared after the extrusion of the as-cast state and the residual intermetallic phases were ordered in rows parallel to the extrusion direction. A variation in the processing related to thermal treatment seriously affects the mechanical and corrosion behavior.
Heat treatment is responsible for the dissolution of the LPSO phases, the structure homogenization, and therefore a decrease of corrosion rate, which was lowered from $2.5 \mathrm{~mm} /$ year to $1 \mathrm{~mm} /$ year in the case of the extruded sample and extruded sample with subsequent thermal treatment, respectively. The presented results also showed that thermal treatment is more favorable before extrusion. In this case, the tensile yield strength reached $337 \mathrm{MPa}$, whereas such a value was 5 times lower for the extruded and the subsequently heat-treated sample.

\section{Acknowledgment}

We wish to thank Czech Science Foundation for financial support of this research by project No. GA1608963S.

\section{REFERENCES}

${ }^{1}$ S. A. Farzadfar, M. Sanjari, I. H. Jung, E. Essadiqi, S. Yue, Role of yttrium in the microstructure and texture evolution of Mg, Materials Science and Engineering: A 528 (2011) 22, 6742-6753, doi:10.1016/j.msea.2011.05.064

${ }^{2}$ H. Liu, F. Xue, J. Bai, J. Zhou, Y. Sun, Microstructures and Mechanical Properties of Mg-2Y-xZn ( $\mathrm{x}=1,2,3$ at.\%) Alloys, Rare Metal Materials and Engineering 43 (2014) 3, 570-574, doi:10.1016/ S1875-5372(14)60079-5

${ }^{3}$ J.-X. Yi, B.-Y. Tang, P. Chen, D.-L. Li, L.-M. Peng, W.-J. Ding, Crystal structure of the mirror symmetry $10 \mathrm{H}$-type long-period stacking order phase in $\mathrm{Mg}-\mathrm{Y}-\mathrm{Zn}$ alloy, Journal of Alloys and Compounds 509 (2011) 3, 669-674, doi:10.1016/j.jallcom.2010.09.140

${ }^{4}$ S. Cabeza, G. Garcés, P. Pérez, P. Adeva, Properties of WZ21 (\%wt) alloy processed by a powder metallurgy route, Journal of the Mechanical Behavior of Biomedical Materials 46 (2015), 115-126, doi:10.1016/j.jmbbm.2015.02.022

${ }^{5}$ T. A. Grünewald, A. Ogier, J. Akbarzadeh, M. Meischel, H. Peterlik, S. Stanzl-Tschegg, J.F. Löffler, A. M. Weinberg, H. C. Lichtenegger, Reaction of bone nanostructure to a biodegrading Magnesium WZ21 implant - A scanning small-angle X-ray scattering time study, Acta Biomaterialia 31 (2016), 448-457, doi:10.1016/j.actbio.2015.11.049

${ }^{6}$ T. Kekule, B. Smola, M. Vlach, H. Kudrnova, V. Kodetova, I. Stulikova, Thermal stability and microstructure development of cast and powder metallurgy produced $\mathrm{Mg}-\mathrm{Y}-\mathrm{Zn}$ alloy during heat treatment, Journal of Magnesium and Alloys 5 (2017) 2, 173-180, doi:10.1016/j.jma.2017.05.004

${ }^{7}$ N. I. Zainal Abidin, B. Rolfe, H. Owen, J. Malisano, D. Martin, J. Hofstetter, P.J. Uggowitzer, A. Atrens, The in vivo and in vitro corrosion of high-purity magnesium and magnesium alloys WZ21 and AZ91, Corrosion Science 75 (2013), 354-366, doi:10.1016/ j.corsci.2013.06.019

${ }^{8}$ T. P. Flaten, Aluminium as a risk factor in Alzheimer's disease, with emphasis on drinking water. Brain Research Bulletin 55 (2001) 2, 187-196, doi:10.1016/S0361-9230(01)00459-2

${ }^{9}$ Z. Q. Yang, S. Y. Ma, Q. M. Hu, H. Q. Ye, M. F. Chisholm, Direct observation of solute interstitials and their clusters in $\mathrm{Mg}$ alloys, Materials Characterization 128 (2017), 226-231, doi:10.1016/ j.matchar.2017.04.003

${ }^{10}$ J. Kubásek, D. Dvorský, M. Čavojský, D. Vojtěch, N. Beronská, M. Fousová, Superior Properties of Mg-4Y-3RE-Zr Alloy Prepared by Powder Metallurgy, Journal of Materials Science \& Technology, 33 (2017) 7, 652-660, doi:10.1016/j.jmst.2016.09.019

${ }^{11}$ J. Y. Lee, D. H. Kim, H. K. Lim, D. H. Kim, Effects of Zn / Y ratio on microstructure and mechanical properties of $\mathrm{Mg}-\mathrm{Zn}-\mathrm{Y}$ alloys, 
Materials Letters 59 (2005) 29-30, 3801-3805, doi:10.1016/ j.matlet.2005.06.052

${ }^{12}$ D. K. Xu, L. Liu, Y. B. Xu, E. H. Han, The influence of element Y on the mechanical properties of the as-extruded $\mathrm{Mg}-\mathrm{Zn}-\mathrm{Y}-\mathrm{Zr}$ alloys, Journal of Alloys and Compounds 426 (2006) 1-2, 155-161, doi:10.1016/j.jallcom.2006.02.035

${ }^{13}$ E. Zhang, W. He, H. Du, K. Yang, Microstructure, mechanical properties and corrosion properties of $\mathrm{Mg}-\mathrm{Zn}-\mathrm{Y}$ alloys with low $\mathrm{Zn}$ content, Materials Science and Engineering: A 488 (2008) 1-2, 102-111, doi:10.1016/j.msea.2007.10.056

${ }^{14}$ T. J. Chen, W. Wang, D. H. Zhang, Y. Ma, Y. Hao, Development of a new magnesium alloy ZW21, Materials \& Design 44 (2013), 555-565, doi:10.1016/j.matdes.2012.08.040

${ }^{15}$ E. Abe, A. Ono, T. Itoi, M. Yamasaki, Y. Kawamura, Polytypes of long-period stacking structures synchronized with chemical order in a dilute $\mathrm{Mg}-\mathrm{Zn}-\mathrm{Y}$ alloy, Philosophical Magazine Letters 91 (2011) 10, 690-696, doi:10.1080/09500839.2011.609149

${ }^{16}$ K. H. Y. Kawamura, A. Inoue, T. Masumoto, Rapidly Solidified Powder Metallurgy Mg97Zn1Y2Alloys with Excellent Tensile Yield Strength above $600 \mathrm{MPa}$, Special Issue on Platform Science and Technology for Advanced Magnesium Alloys 42 (2001) 7, 1172-1176, doi:10.2320/matertrans.42.1172

${ }^{17}$ A. C. Hänzi, A. S. Sologubenko, P. J. Uggowitzer, Design strategy for new biodegradable $\mathrm{Mg}-\mathrm{Y}-\mathrm{Zn}$ alloys for medical applications, International Journal of Materials Research 100 (2009) 8, 1127-1136, doi:10.3139/146.110157

${ }^{18}$ L. Song, B. Wu, L. Zhang, X. Du, Y. Wang, C. Esling, Twinning characterization of fiber-textured AZ31B magnesium alloy during tensile deformation, Materials Science and Engineering: A 710 (2018) 57-65, doi:10.1016/j.msea.2017.10.055
${ }^{19}$ Z. P. Luo, D. Y. Song, S. Q. Zhang, Strengthening effects of rare earths on wrought Mg-Zn-Zr-RE alloys, Journal of Alloys and Compounds 230 (1995) 2, 109-114, doi:10.1016/0925-8388(95)01893-X

${ }^{20}$ M. R. Barnett, A. Sullivan, N. Stanford, N. Ross, A. Beer, Texture selection mechanisms in uniaxially extruded magnesium alloys, Scripta Materialia 63 (2010) 7, 721-724, doi:10.1016/j.scriptamat. 2010.01.018

${ }^{21}$ N. Stanford, M. R. Barnett, The origin of "rare earth" texture development in extruded $\mathrm{Mg}$-based alloys and its effect on tensile ductility, Materials Science and Engineering: A 496 (2008) 1-2, 399-408, doi:10.1016/j.msea.2008.05.045

${ }^{22}$ D. Dvorský, J. Kubásek, D. Vojtěch, I. Voňavková, M. Veselý, M. Čavojský, Structure and mechanical characterization of Mg-Nd-Zn alloys prepared by different processes, IOP Conference Series: Materials Science and Engineering 179 (2017) 1, doi:10.1088/1757899X/179/1/012018

${ }^{23}$ Y. Ding, C. Wen, P. Hodgson, Y. Li, Effects of alloying elements on the corrosion behavior and biocompatibility of biodegradable magnesium alloys: a review, Journal of Materials Chemistry B 2 (2014) 14, 1912-1933, doi:10.1039/C3TB21746A

${ }^{24}$ J. Kubásek, D. Dvorský, M. Čavojský, D. Vojtěch, N. Beronská, M. Fousová, Superior Properties of Mg-4Y-3RE-Zr Alloy Prepared by Powder Metallurgy, Journal of Materials Science \& Technology 33 (2017) 7, 652-660, doi:10.1016/j.jmst.2016.09.019

${ }^{25} \mathrm{~J}$. Li, Q. Jiang, H. Sun, Y. Li, Effect of heat treatment on corrosion behavior of AZ63 magnesium alloy in 3.5 wt.\% sodium chloride solution, Corrosion Science 111 (2016), 288-301, doi:10.1016/ j.corsci.2016.05.019 